\title{
BIOLOGICAL CONTROL OF PRAYS OLEAE (BERN.) BY CHRYSOPIDS IN TRÁS- OS-MONTES REGION (NORTHEASTERN PORTUGAL)
}

\author{
A. Bento \\ Escola Sup. \\ Agrária Bragança, \\ 5300 Bragança \\ J. Lopes \\ Dir. Reg. Agricultura \\ Trás-os-Montes, \\ 5370 Mirandela
}

\author{
L. Torres \\ Univ. Trás-os-Montes \\ Alto Douro, \\ 5000 Vila Real \\ P. Passos-Carvalho \\ Bolseiro JNICT
}

Keywords: chrysopids; olive moth; egg predation; field releases.

\section{Abstract}

A study was carried out in an olive grove in the Trás-os-Montes region, in the period 1993 to 1996 to establish the rate of predation of chrysopids on Prays oleae (Bern.) eggs. Data on a trial conducted in 1996 to evaluate the effectiveness of field releases of Chrysoperla carnea (Steph.) in controlling eggs of the carpophagous generation of the pest are also reported. Six species of Chrysopidae have been collected. The most abundant were $C$. carnea and Mallada flavifrons (Brauer) which together represented about $74 \%$ of total captures. The main period of adult catches occurred between July and October. The rate of predation by chrysopids on $P$. oleae eggs varied among different generations of the pest and in different years, reaching $34 \%$ for the carpophagous generation in 1996. The potential damage that might be expected from the studied population of $P$. oleae was almost halved by releasing 360 larvae of $C$. carnea per tree.

\section{Introduction}

Chrysopids are well known as common and efficient oophagous predators of $P$. oleae in several olive growing areas (Alrouechdi et al., 1981; Niccoli and Boni, 1984; Campos and Ramos, 1983), but their numbers are often inadequate to provide the desired level of pest control. Therefore, efforts to increase the numbers of the predator to improve its real efficiency should be designed to complement naturally occurring populations (Ridgway and Murphy, 1984).

In order to evaluate the biological control potential of chrysopids in reducing $P$. oleae infestation under the conditions of northeastern Portugal, a survey was carried out on the species present in one olive grove sited at a representative olive growing area of the region and the rate of predation on $P$. oleae eggs in natural conditions was evaluated. Moreover, the effect of increasing natural populations of $C$. carnea for control of $P$. oleae eggs of the carpophagous generation was assessed in an experiment undertaken in 1996.

\section{Materials and methods}

The study was carried out in one olive grove near Mirandela, northeastern Portugal, on trees of the variety "Cobrançosa" of about 40 years old. 
From July to December 1994 and from March 1995 to December 1996, adult chrysopids were collected with five McPhail traps baited with a $4 \%$ aqueous solution of biammonium phosphate containing a $1 \%$ solution of borax. Catches were recorded weekly and those from 1996 were removed to the laboratory for identification.

Chrysopids larvae were monitored bi-monthly at about the same period by beating 100 branches, two per tree on each of the 50 randomly selected trees of the orchard.

Predatory activity on eggs was measured from 1993 to 1996, for the anthophagous and carpophagous generations of $P$. oleae and in 1995 and 1996 for the phyllophagous generation. Two samples were collected each year at the point of the life cycle when the percentage of hatched eggs reached nearly 100\%. Each sample consisted of 25 flower clusters, 25 olives or 100 leaves from each of 25 random selected olive trees. For each sampling date the percentage of predated eggs and the percentage of protection (that is the infested olives with all eggs predated) were calculated.

To assess the effect of increasing natural populations of $C$. carnea for control of $P$.oleae eggs of the carpophagous generation, second instar larvae of the predator were obtained from Koopert-Biological Systems, Netherlands, in 1996 and were released in the orchard just at the beginning of $P$. oleae egg-laying period, on the basis of observations in the field. Five treatments $(90,180,360,720$ and 900 larvae per tree) and one control were employed during the course of the study. Each treatment was replicated five times using individual trees as replicates. To evaluate the results, samplings of 25 olives were made at random from the five trees in each treatment, according to the methodology described above.

The differences between the plots in the percentage of fruit infestation, fruit "protection" and egg predation were analysed using the analysis of variance, after testing the homogeneity of variances, followed by a Tukey test.

\section{Results and discussion}

Adult chrysopids were caught in McPhail traps, from the beginning of May to the end of November (figure 1), although the main period of catches (86.8\% of the total insects captured) had occurred between July and October. Larvae trapped in beating samples, even if only a few (61 specimens), were found in the orchard over a relatively large period (beginning of February to mid November) (figure 2). It must be noted that the peak of captures was at about the $P$. oleae ovipositing periods - end of April/beginning of June for the anthophagous generation; July for the carpophagous, and beginning of October/beginning of November for the phyllophagous.

On the basis of 405 specimens of chrysopids collected in McPhail traps, six species were identified. The most abundant was $C$. carnea which represented about $50 \%$ of the total identified, followed by $M$. flavifrons which accounted for $24 \%$ of this total. The other species were, $M$. picteti McLachlan, which made up $13.3 \%$ of chrysopids sampled, $M$. prasina Burmeister which made up $11.1 \%$ of them, Nineta vittata (Wesmael), with only four specimens captured, and Rexa lordina (Navás), with only three specimens.

C. carnea, the most abundant species captured, occurred in the traps from May to November, with a maximum between mid June to mid September at an average of 2.6 adults per trap per week (figure 3). $M$. flavifrons, was captured in three periods: from late spring to early summer; in late summer and in early autumn. Two peaks of captures were recorded, one at the end of June and the other in mid September, reaching an average of respectively, 6.4 and 5.6 insects per trap per week (figure 3). M. picteti, the third species in order of abundance, was found at the end of July, with only two specimens in the five traps, and after this, from the beginning of September to the beginning of October. A marked peak of captures (7.6 individuals per trap per week) occurred by mid September. $M$. prasina, was captured at about the same periods as $M$. flavifrons, although in smaller numbers. The 
maximum of captures was recorded in the second half of September, with an average of 3.0 specimens per trap per week.

$C$. carnea was the only species to be found during the whole ovipositing period of $P$. oleae. It is probable that $M$. flavifrons and $M$. prasina larvae could also contribute to the predation of $P$. oleae eggs of the carpophagous and phyllophagous generations, while $M$. picteti could only do it on the later generation.

Predator activity due to natural populations of chrysopids varied between generations and years (table 1). Predation rates were greater in the carpophagous generation than in either anthophagous or phyllophagous, except in 1995 when they were greater in the phyllophagous.

As during the carpophagous generation there is normally a certain degree of egg accumulation on the fruits, the predator activity will only be of value if all eggs laid on a particular fruit are destroyed. Real efficiency of predation can therefore be expressed as the percentage of "protected" fruits (Alrouechdi, 1980), that is those fruits with all eggs predated. During the four years studied, the most common frequency of $P$. oleae eggs per fruit was, 1 , 2 and 3, and the rate of "protected" fruits varied between 8.7 and 27.7\%, 1996 being the year with the higher rate (table 1).

The success of increasing populations of $C$. carnea for control of $P$. oleae eggs varied, within certain limits, with the number of larvae released per tree (table 2). All predator treatments, including the lowest 90 larvae per tree had a measurable impact in increasing the rate of egg predation and that of fruit "protection", our integral measure of efficacy. The impact on fruit infestation rate was only measurable when 180 larvae were released per tree. Also, the rates of egg predation, fruit "protection" and fruit infestation were not significantly different in trees where 900 larvae were released from those where 360 larvae were released. The later treatment gave reductions of about $12.6 \%$ in the rate of fruit infestation while it gave increases of $26.8 \%$, and $24.0 \%$ in the rates of respectively fruit "protection" and egg predation (table 2). Expressed differently, the potential damage that might be expected from the studied population of $P$. oleae (expressed in terms of the rate of fruit "protection"), was almost halved by releasing 360 larvae of $C$. carnea per tree.

In conclusion this study showed that it is possible to improve the effectiveness of the chrysopid found in olive groves by increasing their natural populations. However practical use of these predators can only be considered within the context of an integrated control program. In addition, implementation of such a strategy would be primarily dependent on labour and chrysopid costs.

\section{Acknowledgements}

Research work supported by project PAMAF IED n ${ }^{\circ} 6117$

\section{$\underline{\text { References }}$}

Alrouechdi, K.1980. Les Chrysopides en verger d'olivier. Bio-Ècologie de Chrysoperla carnea (Steph.) (Neuroptera, Chrysopidae), rélations comportamentales et throphiques avec certain espéces phytophages. Thése Doc. Ing., Paris VI, 198 pp.

Alrouechdi, K.; Pralavorio, R.; Canard, M. and Arambourg, Y. 1981. Coincidence et relations prédatrices entre Chrysoperla carnea (Stephens) (Neur. Chrysopidae) et quelques ravageurs de l'olivier dans le sud-est de la France. Bull.Soc.Ent.Suisse, 54: 281 290.

Campos, M. and Ramos, P. 1983. Chrysopidos (Neuroptera) capturados en un olivar del sur de España. Neur. Int., 2(4): 219-227. 
Ridgway, R.L. and Murphy, W.L., 1984. Biological control in the field. Biological and integrated control by chrysopids. In: Canard, M., Séméria, Y., New, T.R. (eds). Biology of Chrysopidae. Dr. Junk Publishers, The Hague, Boston, Lancaster: 220: 228.

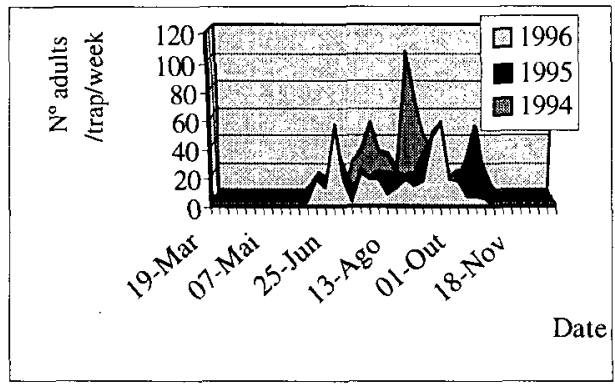

Figure 1. Mean number of adult chrysopids caught per trap per week on McPhail traps.
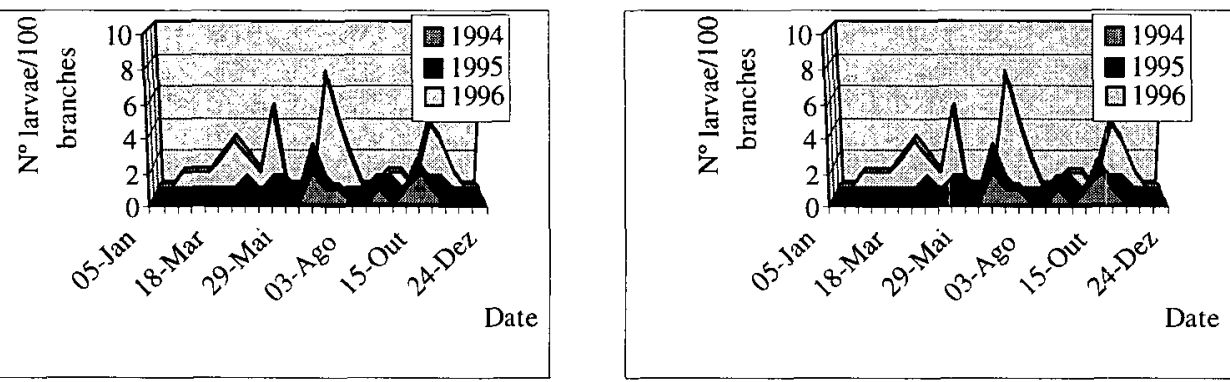

Figure 2. Total number of larvae of chrysopids caught per 100 branches by beating method.

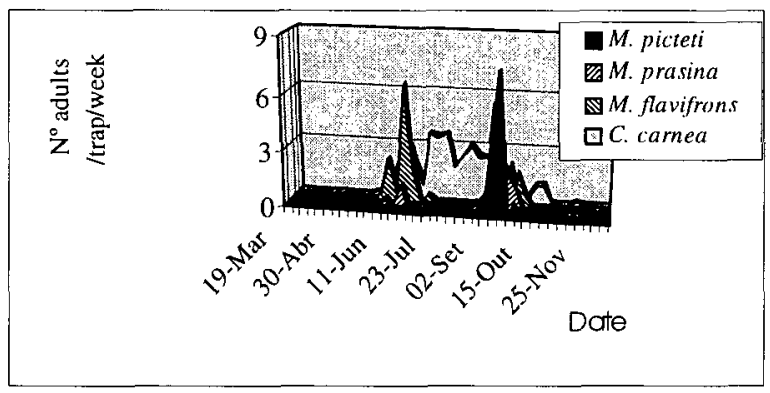

Figure 3. Mean number of adults of each of the major chrysopid species caught per trap per week on McPhail traps in 1996. 
Table 1. Rate of predated eggs of $P$. oleae at Mirandela. For the carpophagous generation data are also presented on the rate of "protected" fruits

\begin{tabular}{lcccc}
\multicolumn{5}{c}{ Year } \\
\hline & 1993 & 1994 & 1995 & 1996 \\
Phyllophagous & - & - & 21.0 & 9.5 \\
Antophagous & 5.9 & 9.5 & 1.8 & 6.8 \\
Carpoph. predated & 19.7 & 11.3 & 19.7 & 34.3 \\
«protected» & 9.1 & 8.7 & 17.9 & 27.7 \\
\hline
\end{tabular}

Means with different letters differ significantly at $5 \%$ level based on Tukey test

Table 2. Fruit infestation rates due to eggs of $P$. Oleae as affected by the number of $C$. carnea releases. Data are also shown on the predation and "protection" rates

\begin{tabular}{cccc}
\hline predators released per & $\begin{array}{c}\text { \% fruit } \\
\text { infestation } *\end{array}$ & $\begin{array}{c}\text { \% egg } \\
\text { predation } *\end{array}$ & $\begin{array}{c}\% \text { fruit } \\
\text { "protection"* }\end{array}$ \\
0 & $36.6 \mathrm{a}$ & $32.0 \mathrm{a}$ & $27.8 \mathrm{a}$ \\
90 & $30.8 \mathrm{a}$ & $49.0 \mathrm{~b}$ & $45.0 \mathrm{~b}$ \\
180 & $28.4 \mathrm{~b}$ & $50.1 \mathrm{~b}$ & $47.6 \mathrm{~b}$ \\
360 & $24.0 \mathrm{bc}$ & $56.0 \mathrm{bc}$ & $54.6 \mathrm{bc}$ \\
720 & $22.8 \mathrm{bc}$ & $60.7 \mathrm{bc}$ & $57.4 \mathrm{bc}$ \\
900 & $17.2 \mathrm{c}$ & $68.8 \mathrm{c}$ & $63.2 \mathrm{c}$ \\
\hline
\end{tabular}

Means with different letters differ significantly at $5 \%$ level based on Tukey test 